\title{
Localization of follistatin in the rat testis
}

\author{
A. Meinhardt", M. K. O’Bryan, J. R. McFarlane ${ }^{\dagger}$, K. L. Loveland, \\ C. Mallidis, L. M. Foulds, D. J. Phillips and D. M. de Kretser
}

Institute of Reproduction and Development, Monash University, Clayton, Victoria 3168, Australia

\begin{abstract}
The cellular localization of the activin-binding protein, follistatin, in the rat testis has been a matter of some controversy with different investigators claiming that Sertoli cells, Leydig cells or germ cells are the primary cell types containing this protein. The localization of mRNA encoding follistatin was re-examined using reverse transcription-polymerase chain reaction (RT-PCR) and in situ hybridization as well as the distribution of follistatin by immunohistochemistry. The results demonstrate that mRNA encoding follistatin is located in many germ cells including type B spermatogonia, primary spermatocytes with the exception of the late leptotene and early zygotene stages, and spermatids at steps 1 to 11 . It is also found in Sertoli cells and endothelial cells but not in Leydig cells. Immunohistochemistry, using two different antisera to follistatin, showed that this protein was localized to spermatogonia, primary spermatocytes at all stages except the zygotene stage, spermatids at all stages and to endothelial cells and Leydig cells in the intratubular regions. The failure to detect mRNA for follistatin in Leydig cells using RT-PCR and in situ hybridization suggests that the immunohistochemical localization in these cells reflects binding of follistatin produced elsewhere. The widespread localization of follistatin, taken together with its capacity to neutralize the actions of activin, may indicate that follistatin modulates a range of testicular actions of activin, many of which remain unknown.
\end{abstract}

\section{Introduction}

There is increasing evidence that, in addition to their action on the secretion of pituitary FSH, inhibin and activin have local effects within the testis which include modulation of steroidogenesis and spermatogonial multiplication (Hseuh et al., 1987; Mather et al., 1990). The action of activin involves several transmembrane serine-threonine kinase receptors (see Mathews 1994, for review), but can also be modulated by the activin-binding protein follistatin (Mather et al., 1993) which has been shown to bind activin with a $K_{\mathrm{d}}$ value ranging from 0.05 to $0.90 \mathrm{nmol} \mathrm{I}^{-1}$ (Nakamura et al., 1990; Kogawa et al., 1991a; Sugino et al., 1993; Schneyer et al., 1994).

Follistatin was isolated from follicular fluid using its capacity to suppress FSH secretion by pituitary cells for the detection of its activity (Robertson et al., 1987; Ueno et al., 1987). Follistatin is a product of a single gene of approximately 6 kilobases and consists of six exons (Shimasaki $e t$ al, 1988; Shimasaki et al., 1989). Two distinct mRNA forms are generated by alternative splicing resulting in two proteins (FS344 and FS317). FS317 lacks a highly acidic carboxy terminal extension which is present in FS344. Both variants are proteolytically processed, with FS344 yielding FS315 and FS300 while FS317 yields FS288. Variable glycosylation of each of these products yields at least six forms of this protein

Present addresses: *Institute of Anatomy and Cell Biology, Philipps University, D-35037 Marburg. Germany; ${ }^{\dagger}$ Department of Physiology, University of New England, Armidale, New South Wales 2350 Australia.

Received 6 June 1997. with molecular masses ranging from 31 to $45 \mathrm{kDa}$ (Robertson et al., 1987; Ueno et al., 1987; Sugino et al., 1993). The capacity of each form of follistatin to bind activin is similar (Sugino et al, 1993), but FS288 binds strongly to heparan sulphate proteoglycans with FS315 showing no similar capacity (Sugino et al., 1993). Consequently the mRNA splice variations appear to result in a multiplicity of forms with different physiological actions.

Knowledge of the physiology of follistatin is intricately linked to an understanding of the actions of activin, but there is limited information concerning follistatin in the testis. Using a ribonuclease protection assay, Michel et al. (1993) demonstrated mRNA encoding follistatin in immature rat Sertoli cells with the predominant message being FS344. In that study, production of follistatin mRNA was stimulated by epidermal growth factor through the protein kinase $C$ pathway but not via FSH. In addition, Kaipia et al. (1992) demonstrated by in situ hybridization that follistatin mRNA was localized to the Sertoli cells, particularly from stages IX to XI. However, using immunocytochemistry, Kogawa et al. (1991b) could not show Sertoli cell localization, but detected follistatin immunoactivity in Leydig cells and in the nuclei of spermatocytes and spermatids.

In view of the conflicting data concerning the localization of follistatin mRNA and protein, we have carried out studies using immunocytochemistry and in situ hybridization on whole rat testis sections as well as RT-PCR on mRNA from enriched preparations of testicular cells to clarify the cellular localization of this important mediator. 


\section{Materials and Methods}

\section{Animals}

Adult and 20 day post-partum male Sprague Dawley rats were obtained from the Monash University Central Animal breeding house. These investigations were approved by the Monash University Standing Committee on Ethics in Animal Experimentation and conformed to the National Health and Medical Research Council/CSIRO/AAC Code of Practice for the Care and Use of Animals for Experimental Purposes.

\section{Preparation of tissues for immunohistochemistry and in situ hybridization}

Testes of adult rats were fixed by vascular perfusion using Bouin's fluid and then immersed for a further $5 \mathrm{~h}$, dehydrated and embedded in paraffin wax. Sections were cut at 5-6 $\mu \mathrm{m}$, deparaffinized and subsequently passed through decreasing concentrations of alcohol into water.

\section{Isolation of testicular cell types}

Highly enriched preparations of rat Leydig cells ( $96 \%$ pure), round spermatids ( $90 \%$ pure) and primary spermatocytes $(86 \%$ pure) were obtained from adult rat testes, and Sertoli cells ( $95 \%$ pure) were isolated from testes from rats at 20 days postpartum, following previously reported methods (Loveland et al., 1993). Cell pellets were snap frozen in dry ice immediately after isolation.

\section{Preparation of RNA}

Total RNA was isolated from preparations according to the method of Chomczynski and Sacchi (1987). The RNA concentration of each sample was estimated by measuring the absorbance at $260 \mathrm{~nm}$.

\section{Reverse transcription and polymerase chain reaction (PCR)}

Reverse transcription (RT) was performed using $1 \mu \mathrm{g}$ of total RNA denatured at $65^{\circ} \mathrm{C}$ for $5 \mathrm{~min}$ as the template in a $20 \mu \mathrm{l}$ reaction volume with $20 \mathrm{pmol}$ oligo(dT) ${ }_{15}$ (Promega Corporation, Madison, WI). RNasin (10 U per sample), AMV reverse transcriptase ( $1.5 \mathrm{U}$ per sample) and dNTPs ( $1 \mathrm{mmol}$ $1^{-1}$ final concentration) were purchased from Promega; dithiothreitol (used at $6.7 \mathrm{mmol} \mathrm{l}^{-1}$ ) was supplied by Sigma Chemical Company. The reaction was performed in $1 \times \mathrm{RT}$ buffer (10 $\times$ buffer: $670 \mathrm{mmol}$ Tris- $\mathrm{HCl} \mathrm{l}^{-1}, \mathrm{pH} \mathrm{8.8;166} \mathrm{mmol}$ $\left(\mathrm{NH}_{4}\right) \mathrm{SO}_{4} \mathrm{l}^{-1} ; 4.5 \%(\mathrm{v} / \mathrm{v})$ Triton X-100; $2 \mathrm{mg}$ gelatin $\mathrm{ml}^{-1}$ and $9 \mathrm{mmol} \mathrm{MgCl}_{2} \mathrm{l}^{-1}$ ) supplied by the manufacturer of the enzyme used in the subsequent PCR (Tth Plus, Biotech International Ltd, Bentleigh, Western Australia). After incubation at $42^{\circ} \mathrm{C}$ for $60 \mathrm{~min}$ the product was heated to $95^{\circ} \mathrm{C}$ for $2 \mathrm{~min}$.

Each PCR sample was in a final volume of $20 \mu$ l containing $5 \mu \mathrm{l}$ of the RT sample, $I \times$ buffer, I.I unit of Tth Plus and 20 pmol of each primer. The rat FS oligonucleotide primers $\left(5^{\prime}\right.$ to $\left.3^{\prime}\right)$ were (FS3) TTC CCT CTG TGA TGA GCT CTG and
(FS4) GAT GGG GGA ATA CAG GGG AGC TG synthesized at the Department of Microbiology (Monash University, Clayton). PCR was performed in a Perkin Elmer DNA Thermocycler with the following cycling conditions: one cycle of $2 \mathrm{~min}$ each at $95^{\circ} \mathrm{C}, 55^{\circ} \mathrm{C}$ and $72^{\circ} \mathrm{C}$; thirty cycles of $95^{\circ} \mathrm{C}$ $(30 \mathrm{~s}), 55^{\circ} \mathrm{C}(30 \mathrm{~s})$ and $72^{\circ} \mathrm{C}(1 \mathrm{~min})$; one cycle of $2 \mathrm{~min}$ at $72^{\circ} \mathrm{C}$. These conditions were established after a series of experiments using different temperatures and cycles and under all conditions the primer dimers were present. The samples were analysed by agarose gel electrophoresis in I X TAE (Sambrook et al., 1989) in the presence of a DNA standard (pGEM and pUC19, Promega). Under these conditions and using the primers described, FS344 gave an amplified band of 470 bp and FS317 gave an amplified signal at $205 \mathrm{bp}$.

The DNA for sequencing was isolated by subjecting the bands to electrophoresis into a well cut in the gel. The DNA was collected from the well, separated from salts on a NICK column (Pharmacia Biotech, Uppsala) and lyophilized to concentrate the DNA. PCR products were sequenced using an Applied Biosystems Automated sequencer and dye-terminator sequencing by the Department of Microbiology (Monash University).

\section{In situ hybridization}

A riboprobe was prepared from the follistatin probe designed by Michel et al. (1990), the characteristics of which were described above and labelled with digoxigenin using the method outlined in the Boehringer Mannheim riboprobe labelling kit. Labelled sense and antisense cRNA was synthesized by incubating linearized template $(\mathrm{I} \mu \mathrm{g})$ with dig-labelled UTP ( $3.5 \mathrm{mmol} \mathrm{l}^{-1}$ ) in the presence of T7 or SP6 RNA polymerase for the appropriate restrictive enzyme used for the antisense (EcoRI) and sense (Pst I) restriction enzymes used, for $2 \mathrm{~h}$ at $37^{\circ} \mathrm{C}$.

For in situ hybridization, sections were dewaxed using histolene (Fronine Pty Ltd, Riverview) and rehydrated through graded ethanols. Accessibility of the probe was increased by treating sections with $0.2 \mathrm{~mol} \mathrm{HCl}^{-1}$ for $20 \mathrm{~min}$ and partially digesting them with proteinase $\mathrm{K}\left(5 \mu \mathrm{g} \mathrm{ml}{ }^{-1}\right)$ for $30 \mathrm{~min}$ at $37^{\circ} \mathrm{C}$. After incubation with $0.2 \%(\mathrm{v} / \mathrm{v})$ glycine for $10 \mathrm{~min}$ at $4^{\circ} \mathrm{C}$, sections were acetylated in $0.25 \%(\mathrm{v} / \mathrm{v})$ acetic anhydride and prehybridized for a minimum of $2 \mathrm{~h}$ at $42^{\circ} \mathrm{C}$. Prehybridization solution was composed of $3 \times$ SSC $(I \times$ SSC contains $0.15 \mathrm{~mol}$ sodium chloride $1^{-1}, 15 \mathrm{mmol}$ sodium citrate $\mathrm{l}^{-1}$, $\mathrm{pH} 7, \quad 1 \times$ Denhardt's solution, $50 \%$ deionized formamide, $66 \mathrm{mmol}$ phosphate buffer $\mathrm{I}^{-1} \mathrm{pH} \mathrm{8}, 1000 \mu \mathrm{g}$ herring sperm DNA $\mathrm{ml}^{-1}$ and $200 \mu \mathrm{g}$ yeast RNA ml ${ }^{-1}$. Hybridization was performed overnight at $50^{\circ} \mathrm{C}$ in hybridization buffer consisting of prehybridization buffer plus $10 \%(\mathrm{w} / \mathrm{v})$ dextran sulphate (Pharmacia Biotech) containing a pre-determined concentration (300 $\mathrm{ng} \mathrm{ml}^{-1}$ ) of digoxigenin-labelled probe. Excess probe was removed by sequential $15 \mathrm{~min}$ washes in $2 \times \mathrm{SSC}$ at room temperature, $2 \times \operatorname{SSC}$ at $42^{\circ} \mathrm{C}, 1 \times \mathrm{SSC}$ at $42^{\circ} \mathrm{C}$ and $0.1 \times \mathrm{SSC}$ at $42^{\circ} \mathrm{C}$. Hybridized probe was localized on sections using an anti-digoxigenin alkaline phosphatase conjugated antibody (diluted 1:1000). Excess antibody was removed by washing in $0.1 \mathrm{~mol}$ maleic acid $\mathrm{l}^{-1}, 0.15 \mathrm{~mol} \mathrm{NaCl}{ }^{-1}, \mathrm{pH}$ 7.5. Nonspecific antibody binding was minimized by preincubating 
sections in blocking solution (Boehringer Mannheim, Mannheim) for $30 \mathrm{~min}$ at room temperature. Tissue mRNA:digoxigenin-cRNA dimers were visualized by an enzyme catalysed colour reaction using 5-bromo-4-chloro-3indolyl phosphate (BCIP) and nitroblue tetrazolium salt (NBT) (NBT/BCIP One-Step; Pierce, Rockford, IL). Sections were counterstained with Mayer's haematoxylin and mounted under glass coverslips using GVA histomount (Zymed, San Francisco, CA).

\section{Immunohistochemistry}

Two antisera raised in rabbits were used for immunohistochemistry. Antiserum no. 202 was raised against $39 \mathrm{kDa}$ bovine follistatin and in radioimmunoassays detects the 35,39 and $45 \mathrm{kDa}$ forms of follistatin (Klein et al, 1991). The second, no. JM19, was raised against human recombinant follistatin 288, kindly provided by the National Hormone and Pituitary Program (NIH, Rockville, MD). Antigen retrieval was per-

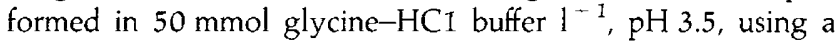
microwave oven. The specimens were incubated for $2-3 \mathrm{~min}$ at approximately $90^{\circ} \mathrm{C}$ before keeping them for another $8-9 \mathrm{~min}$ at 'defrost' intensity. The sections were allowed to cool down to room temperature and were washed twice in $50 \mathrm{mmol}$ phosphate buffered saline $1^{-1}$ (PBS). Pretreatment with 3\% $\mathrm{H}_{2} \mathrm{O}_{2}$ in PBS was performed for $30 \mathrm{~min}$ in the dark to inactivate endogenous peroxidases. Tissue sections were incubated in blocking solution provided by the universal streptavidin-biotin (LSAB)/horseradish peroxidase kit (Dako Co, Botany, NSW) to minimize non-specific antibody binding. Sections were rinsed in PBS/ $0.05 \%$ (v/v) Tween-20 and incubated overnight at $4^{\circ} \mathrm{C}$ with diluted antiserum against follistatin at $1: 200$ in PBS/0.1\% $(\mathrm{w} / \mathrm{v}) \mathrm{BSA}$ followed by three washes in PBS containing $0.05 \%$ Tween-20. The following steps were performed using the universal-LSAB/horseradish peroxidase kit (Dako) according to the manufacturer's instructions. Sections were stained with 3,3'-diaminobenzidine tetrahydrochloride (DAB, Sigma) as chromogen $(0.035 \%(\mathrm{w} / \mathrm{v}) \mathrm{DAB}$ and $0.015 \%$ $\mathrm{H}_{2} \mathrm{O}_{2}$ in 50 mmol sodium acetate buffer $1^{-1}, \mathrm{pH} 6.0$ ). After immersing in distilled water, sections were counterstained with Mayer's haematoxylin and coverslips were mounted using aqueous mounting media. Pre-immune serum and non-specific rabbit serum were used as negative controls instead of a primary antibody.

\section{Sodium dodecyl sulphate-polyacrylamide gel electrophoresis (SDS-PAGE) and western blotting}

Human recombinant follistatin 288 (1000 ng) and bovine follistatin (35, 39 and $45 \mathrm{kDa}$ heterologous pool; $150 \mathrm{ng}$ ) were run on a $12.5 \%$ polyacrylamide non-reducing gel (Laemmli, 1970) and separated proteins were detected by silver staining (Wray et al., 1981). Furthermore, human recombinant follistatin 288 (1250 ng and $2500 \mathrm{ng}$ ) and bovine follistatin (300 ng and $1200 \mathrm{ng}$ ) were run on two identical $12.5 \%$ polyacrylamide non-reducing gels and separated proteins were transferred overnight to $0.22 \mu \mathrm{m}$ pore size nitrocellulose transfer membranes (Schleicher and Schuell, Dassel) at $60 \mathrm{~V}$ with cooling in transfer buffer containing $20 \mathrm{mmol}$ Tris base $1^{-1}, 150 \mathrm{mmol}$ glycine $\mathrm{l}^{-1}, 20 \%(\mathrm{v} / \mathrm{v})$ methanol. At the conclusion of the transfer, the membranes were stained with Ponceau $S$ stain (Sigma) to identify molecular weight marker proteins, and were then blocked for $1 \mathrm{~h}$ with $3 \%$ non-fat dried milk in $20 \mathrm{mmol}$ Tris- $\mathrm{HCl} \mathrm{l} \mathrm{l}^{-1}, 0.15 \mathrm{~mol} \mathrm{NaCl}$ buffer $\mathrm{l}^{-1}$ (TBS) $\mathrm{pH} 8$. The membranes were then incubated with primary antisera, either no. 202 or no. JM19, at a dilution of 1:250 in 1\% non-fat dried milk in $20 \mathrm{mmol} \mathrm{TBS} \mathrm{l}^{-1}$ for $24 \mathrm{~h}$, and then washed several times with $1 \%$ milk/TBS/0.1\% $(\mathrm{v} / \mathrm{v})$ Nonidet P-40 detergent (NP-40, Sigma). The second antiserum used for both membranes was a biotinylated sheep anti-rabbit IgG (Silenus Laboratories, Melbourne) at a dilution of 1:4000 in 1\% milk/ TBS $/ 0.1 \%$ NP-40 for $24 \mathrm{~h}$, followed by several washes as above and enhancement by alkaline phosphatase-conjugated avidin (Pierce) at a dilution of 1:1000. The membranes were then developed with NBT/BCIP One-Step for approximately $10 \mathrm{~min}$.

\section{Results}

PCR

Total RNA from freshly isolated immature Sertoli cells and Percoll-purified preparations of Leydig cells, primary spermatocytes and round spermatids of adult rats was used for RT-PCR to clarify the localization of expression of follistatin mRNA in the testis. The primers were designed to detect both potential splicing variations of the follistatin gene (follistatin 344 and 317). In preparations of Sertoli cells, round spermatids and primary spermatocytes a clear signal of follistatin 317 (amplified band at $205 \mathrm{bp}$ ) was seen (Fig. 1a). The bands were eluted from the gel and a 100\% identity to the rat follistatin gene was confirmed by sequencing (data not shown). An additional faint band comprising follistatin 344 (amplified transcript size $470 \mathrm{bp}$ ) could be identified in the Sertoli cell and round spermatid fraction. Furthermore, using Southern blot hybridization of the gel separating the PCR products, follistatin 344 was also detected in the primary spermatocytes (data not shown). RT-PCR analysis did not permit us to distinguish differences in the relative ratio of follistatin 344:317 due to the kinetics of the reaction. Although both splicing variations theoretically can be detected, in practice the shorter form (follistatin 317) was preferentially amplified (Fig. 1a). No follistatin expression was found in Leydig cells (Fig. Ib).

\section{In situ hybridization}

Follistatin mRNA was found in many germ cells and in Sertoli cells at all stages of the seminiferous cycle. Follistatin mRNA could not be detected in type $A$ and intermediate spermatogonia and small amounts were detected in type B spermatogonia (Figs 2 and 3). Similar amounts were found in preleptotene and leptotene primary spermatocytes but the expression declined in the late leptotene and early zygotene stages (Stages XI and XII). The expression increased slightly in early pachytene stages (Stages XIV to $\mathrm{V}$ ) and reached a maximum in the late pachytene and diplotene stages (Stages VIII to XIV). Follistatin mRNA declined slightly but remained relatively high in spermatids from steps 1 to 10 and declined 
(a)

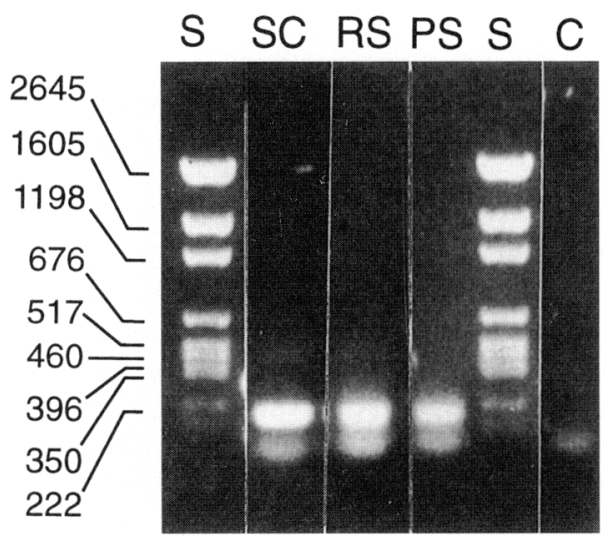

(b)

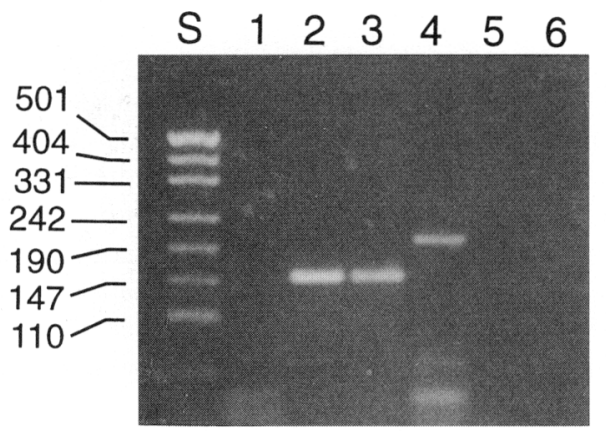

Fig. 1. RT-PCR analysis of expression of mRNA encoding follistatin in different preparations of testicular cells. (a) A clearcut signal of follistatin 317 mRNA (see amplified band at $205 \mathrm{bp}$ ) is visible in Sertoli cells (SC), round spermatids (RS) and primary spermatocytes (PS). A faint band of follistatin 344 (see amplified transcript at $470 \mathrm{bp}$ ) could also be detected in Sertoli cells (SC) and round spermatids (RS). S, Size markers; C, control (water only) (b) The RT-PCR analysis of Leydig cells yielded a negative result for follistatin with only the primer dimers visible (lane 1). The integrity of the Leydig cell mRNA was confirmed by the detection of the housekeeping gene GAPDH (lane 2 and 3). Total testis RNA was used as a positive control for follistatin expression (lane 4). Lanes 5 and 6 are water controls for follistatin and GAPDH. (a) 1\% agarose gel; standard = pGEM. (b) $3 \%$ agarose gel; standard $=$ pUC 19 .

thereafter and was not detected from steps 16 to 19. The detection of mRNA for follistatin in Sertoli cells was difficult to assess because of the thin profiles of cytoplasm and the very strong signal in germ cells, particularly in late primary spermatocytes. The most intense signal in Sertoli cells was seen in stages VI to VIII, which in comparison with the germ cell signal was low. A low signal was detected in Sertoli cells at all stages. In tissue obtained from a rat with congenital absence of germ cells, there was a general expression of follistatin mRNA in all Sertoli cells.

Within the interstitium, the endothelial cells of blood vessels showed follistatin localization and most of the Leydig cells and macrophages did not contain detectable follistatin expression. No obvious localization was seen in the thin profiles of peritubular cells.

\section{SDS-PAGE and western blotting}

On silver staining, the three molecular mass forms of 35 , 39 and $45 \mathrm{kDa}$ were identified in the bovine follistatin heterologous pool (Fig. 4 lane A), with the $39 \mathrm{kDa}$ form staining more intensely than the $35 \mathrm{kDa}$ form, and the $45 \mathrm{kDa}$ form appearing as a diffuse band. In the hr-follistatin 288 preparation (Fig. 4 lane B) the $31 \mathrm{kDa}$ non-glycosylated form stained more intensely than the $35 \mathrm{kDa}$ mono-glycosylated form, while the $40 \mathrm{kDa}$ di-glycosylated form known to be present in this preparation was not evident.

When rabbit antiserum no. 202 was raised against bovine $39 \mathrm{kDa}$ follistatin, three molecular mass forms were identified in the bovine follistatin pool of 35,39 and $45 \mathrm{kDa}$, with the $39 \mathrm{kDa}$ band crossreacting most prominently (Fig. 5 lane A). The hr-follistatin 288 preparation showed a prominent $31 \mathrm{kDa}$ form, with a less intensely crossreacting band of the $35 \mathrm{kDa}$ form, whereas the $40 \mathrm{kDa}$ form was not evident on the blot under the conditions used (Fig. 5 lane B), as on SDS-PAGE analysis. The sensitivity of the interaction of the bovine follistatin with the no. 202 antiserum was approximately 16 times greater than that of the hr-follistatin $288 \mathrm{ng}^{-1}$ protein. Use of rabbit antiserum no. JMI9 led to the identification of three molecular mass forms in the bovine follistatin heterologous pool of 35,39 and $45 \mathrm{kDa}$; the $45 \mathrm{kDa}$ band interacted most prominently (Fig. 5 lane C). The JM19 antiserum detected the same molecular mass forms in the hr-follistatin 288 preparation as did the 202 antiserum (Fig. 5 lane D), but this antiserum reacted equally with both the bovine follistatin and hr-follistatin 288 .

\section{Immunohistochemistry}

The localization of follistatin was similar with the two antibodies; however, some cellular localization was enhanced by a specific antiserum. Within the seminiferous epithelium, spermatogonia of all types showed cytoplasmic localization of follistatin which was particularly strong in type B spermatogonia and was enhanced by antiserum no. JM19 (Fig. 6). Cytoplasmic follistatin was detected in all primary spermatocytes except zygotene (Stage XII) and was particularly marked in preleptotene and leptotene spermatocytes (Stages $X$ and $X I$ ). In spermatids, follistatin was detected in the cytoplasm of all stages and was particularly evident in elongating spermatids using antiserum no. 202. No nuclear localization was found in germ cells with either antiserum.

Follistatin was found in Sertoli cells and did not show any stage-specific increase. Both antisera localized follistatin in Leydig cells. In addition, endothelial cells lining blood vessels showed a significant immunoreaction for follistatin.

\section{Discussion}

This study provides further data concerning the sites of production and localization of follistatin in the rat testis. The 

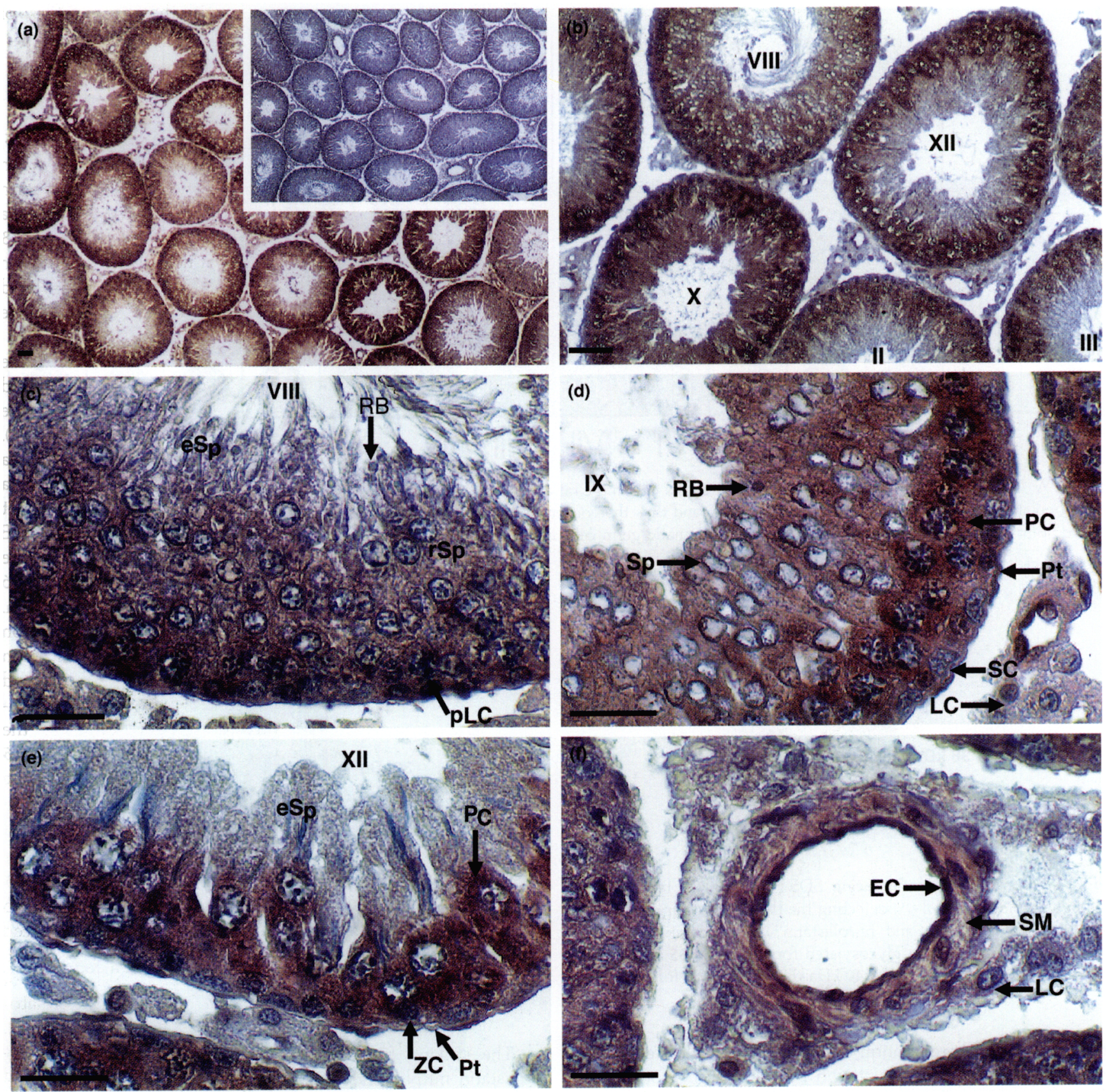

Fig. 2. In situ hybridization analysis of mRNA encoding follistatin within the normal rat testis. (a) A follistatin antisense cRNA probe was hybridized on a section of rat testis. Follistatin was expressed throughout the testis within Sertoli cells and in a subpopulation of germ cells (a inset) A section hybridized with a follistatin sense cRNA probe showing no staining, indicating the specificity of the antisense hybridization. (b) Antisense reaction illustrating the stage specificity of expression of mRNA for follistatin. (c) A stage VIIl seminiferous tubule illustrating the presence of mRNA encoding follistatin in preleptotene spermatocytes, pachytene spermatocytes and round spermatids. Elongating spermatids and residual bodies did not contain appreciable amounts of follistatin message. (d) A stage IX tubule showing intense staining for mRNA encoding follistatin in pachytene spermatocytes. Smaller amounts of message were seen in spermatids, leptotene spermatocytes and Sertoli cells. mRNA encoding follistatin was not seen in peritubular cells or Leydig cells. (c) A stage XII seminiferous tubule showing intense staining for mRNA encoding follistatin in pachytene spermatocytes. Minimal amounts of transcript were detected in elongating spermatids and no message was seen in zygotene spermatocytes or peritubular cells. (f) A region of testicular intertubular space. mRNA encoding follistatin was clearly seen in endothelial cells. Smaller amounts were seen within the smooth muscle layer of blood vessels. Leydig cells did not contain detectable mRNA encoding follistatin. Roman numerals within the lumen indicate the stage of spermatogenesis of the tubule. SC, Sertoli cells; LC, Leydig cells; EC, endothelial cells; SM, smooth muscle; Pt, peritubular cells; $\mathrm{SP}$, round spermatids; eSp, elongating spermatids; Sp, spermatids; PC, pachytene spermatocytes; ZC, zygotene spermatocytes; pLC. preleptotene spermatocytes; RB, residual bodies. Scale bars represent $50 \mu m$. 




Fig. 3. A diagrammatic representation of spermatogenesis within the rat and the relative concentration of mRNA encoding follistatin within germ cell populations. The intensity of germ cell staining, and thus the concentration of mRNA encoding follistatin within germ cells, was graded on a five point scale. Darker background around diagrammatic germ cells is indicative of higher concentrations of mRNA encoding follistatin.

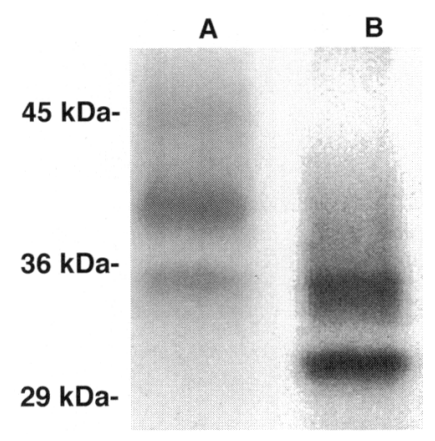

Fig. 4. Silver-stained non-reducing SDS-PAGE gel of bovine follistatin heterologous pool $(A)$ detecting the three molecular mass forms of 35,39 and $45 \mathrm{kDa}$ and hr-follistatin 288 preparation and (B) detecting the $31 \mathrm{kDa}$ non-glycosylated form and the $35 \mathrm{kDa}$ monoglycosylated form, but not the $40 \mathrm{kDa}$ di-glycosylated form.

results reported here confirm that the Sertoli cells are sites of production of follistatin as shown by the presence of mRNA for follistatin 344 by in situ hybridization and the immunohistochemical localization of the protein. Our studies using RT-PCR also confirm the presence of mRNA for follistatin 317 in Sertoli cells, which is consistent with the detection of the follistatin 288 protein with antiserum JM19 which preferentially detects the proteolytically cleaved form.

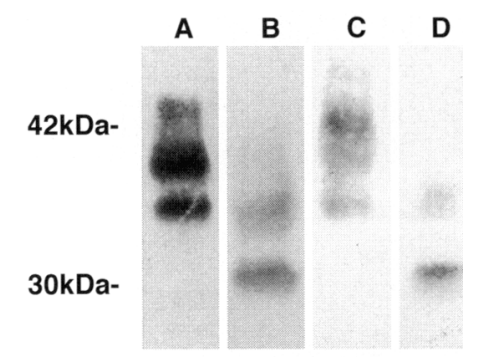

Fig. 5. Western blot of bovine follistatin heterologous pool (containing 35, 39 and $45 \mathrm{kDa}$ forms) (A, $300 \mathrm{ng}$ and $\mathrm{C}, 1200 \mathrm{ng}$ ) and human recombinant follistatin 288 (B, $2500 \mathrm{ng}$ and $\mathrm{D}, 1250 \mathrm{ng}$ ) using antisera no. 202 (lanes $A$ and $B$ ) and no. JM19 (lanes $C$ and D). The blot shows that both antisera can detect the 35, 39, and $45 \mathrm{kDa}$ forms of follistatin in the bovine pool and that both antisera can also detect a prominent $31 \mathrm{kDa}$ form of follistatin together with the $35 \mathrm{kDa}$ form in the recombinant 288 preparation.

The striking finding of this study was the detection of follistatin mRNA and protein in all germ cell types. In most germ cells, the follistatin mRNA and protein detection by in situ hybridization and immunohistochemistry were identical with one exception. Follistatin was detected by immunohistochemistry in all spermatogonia, whereas with in situ hybridization only type $\mathrm{B}$ spermatogonia were found to show follistatin mRNA. The reasons for this discrepancy

Fig. 6. These photomicrographs of the rat testis illustrate the immunohistochemical localization of follistatin in the testis using antiserum no. JM19 and similar patterns were seen with antiserum no. 202. The control shown in (d) used normal rabbit serum instead of antiserum no. JM19. The stages of the seminiferous cycle are indicated. Note the widespread distribution of follistatin in many cell types with particularly marked localization in spermatogonia and leptotene spermatocytes (arrows in (a) and arrowheads in (b)). Zygotene and early pachytene spermatocytes show no localization (arrowheads in (a) and arrows- $Z$ in (b)). Leydig cells and endothelial cells in the interstitium show prominent localization. Scale bar represents $50 \mu \mathrm{m}$. 

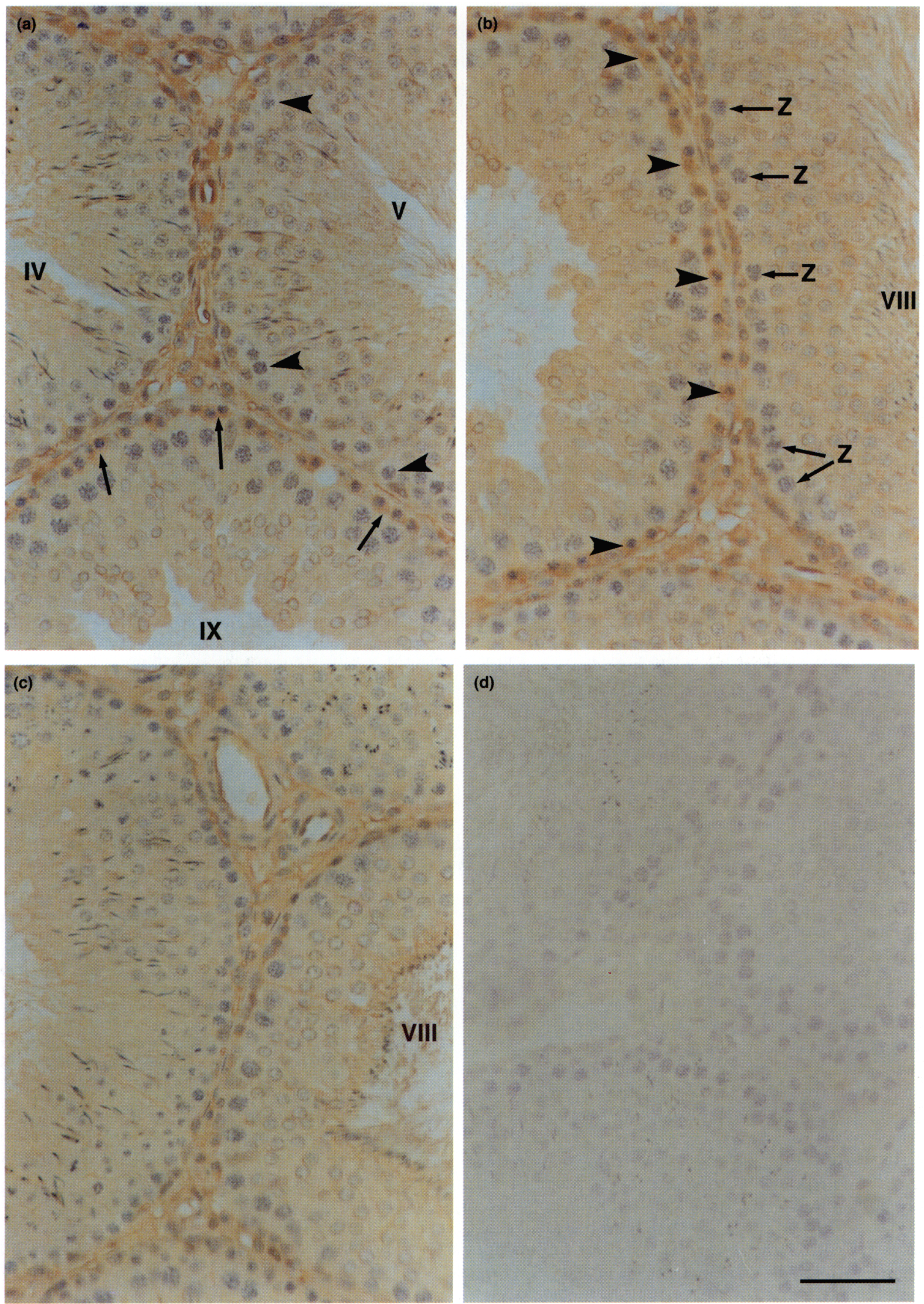

(d) 
are unclear. We were also able to confirm follistatin mRNA in primary spermatocytes, round spermatids and Sertoli cells by RT-PCR. Unfortunately, spermatogonial preparations of sufficiently high purity were not available for RT-PCR.

In view of the absence of follistatin from mid- to late zygotene spermatocytes and the demonstration that late pachytene to diplotene spermatocytes show maximum amounts of mRNA, it can be concluded that the abundance of mRNA is regulated in a stage-specific manner. The nature of the mechanisms involved in this regulation are not known. These results establish that germ cells, which have been shown to contain activin type IIB receptor RNA (de Winter et al., 1992), are capable of producing an activin-binding protein, namely follistatin, which can neutralize the biological actions of activin (Mather et al., 1993). This potential local control mechanism may be important in modulating the stimulation of spermatogonial mitosis by activin or the differentiation of spermatocyte mitochondria induced by activin (Meinhardt et al., 1996). The role of follistatin in modulating the actions of activin on germ cells must remain ill-defined until further data become available to indicate the physiological roles of activin at these sites. The latter are difficult to elucidate in postmeiotic cells since they survive poorly in vitro. In this context, the failure to identify follistatin by immunohistochemistry in zygotene spermatocytes suggests that follistatin production may be regulated.

We were unable to confirm the nuclear localization of follistatin in spermatocytes and spermatids as described by Kogawa et al. (1991b). Our data with regard to germ cell expression of follistatin mRNA contrasts with the data of Kaipia et al. (1992) obtained by in situ hybridization, which localized follistatin mRNA to Sertoli cells only at Stages IX-XI of the rat seminiferous cycle. It is of interest that preleptotene and leptotene spermatocytes are also found at the base of the tubules at these stages of the cycle and the signals noted by Kaipia et al. (1992) may also represent RNA in these spermatocyte stages given the limited resolution of the ${ }^{35} \mathrm{~S}-$ labelled probes used in their study. In fact examination of their figures and figure legends confirm that profiles consistent with follistatin RNA localization in leptotene spermatocytes are seen.

Our immunohistochemical studies showed that follistatin protein is found in Sertoli cells throughout the entire cycle of the seminiferous epithelium in contrast to the sharply localized mRNA found by others at stages IX-XI (Kaipia et al. 1992). Our in situ hybridization results detected a low signal throughout the seminiferous cycle with peak values at stages VII-VIII, slightly earlier than the expression noted by Kaipia et al. (1992). Some of the difficulty in designating semi-quantitative amounts of Sertoli cell mRNA may result from the extremely thin cytoplasmic processes of these cells which appear between germ cells.

Our studies have been unable to demonstrate follistatin mRNA in Leydig cells either by in situ hybridization or by RT-PCR. This contrasts with the immunocytochemical detection of this protein in our study and the observations of Kogawa et al. (1991b). Therefore, it is likely that this localization represents follistatin produced elsewhere and bound to the Leydig cells, most likely to heparan sulphate proteoglycans, a property of follistatin identified by Nakamura et al. (1991). In support of this view, we noted that if antigen retrieval was not used, the follistatin immunostaining of Leydig cells was confined to the cell surface (data not shown). Furthermore, Nakamura et al. (1996) have shown that follistatin bound to heparan sulphate proteoglycans can bind activin and this is followed by uptake of a follistatin-activin complex into lysosomes. In this context, the production of follistatin within the seminiferous epithelium and its binding to Leydig cells may represent a paracrine mechanism perhaps related to the modulation of the action of activin on Leydig cell steroidogenesis (Hsueh et al., 1987, Lin et al., 1989). The observation of follistatin localization to the endothelial cells of testicular blood vessels is consistent with the observations of Inoue et al. (1993) who noted that both activin and follistatin can be found in endothelial cells in other tissues and that they both accumulate at the sites of atheromatous plaques. Furthermore, Michel et al. (1996) have shown that lipopolysaccharides can upregulate follistatin mRNA in endothelial cells in culture, which is in keeping with our demonstration that the administration of interleukin $1 \beta$ markedly stimulates follistatin secretion in vivo (Phillips et al., 1996).

The results of this study emphasize the value of using complementary techniques that permit a high degree of cellular resolution to document sites of mRNA and protein production within the testis. The use of a non-radioactive detection system for in situ hybridization has facilitated confirmation of the germ cell origin of follistatin mRNA and protein by RT-PCR and immunohistochemistry. Discrimination between signals from germ cells and from Sertoli cells at the base of the seminiferous epithelium would otherwise be imprecise if not impossible. Similarly, discrimination between cell types in the interstitium makes the current results a clear guide for future experiments designed to understand the physiological roles of activin and its binding protein, follistatin.

\section{References}

Chomczynski P and Sacchi N (1987) Single step method of RNA isolation by guanidinium thiocyanate-phenol-chloroform extraction Analytical Biochemistry 162 156-159

de Winter JP, Themmen APN, Hoogerbrugge JW, Klaij IA, Grottegoed JA and de Jong FH (1992) Activin receptor mRNA expression in rat testicular cell types Molecular and Cellular Endocrinology 83 RI-R8

Hsueh AJ, Dahl KD, Vaughan J, Tucker E, Rivier J, Bardin CW and Vale W (1987) Heterodimers and homodimers of inhibin subunits have different paracrine action in the modulation of luteinizing hormone-stimulated androgen biosynthesis Proceedings of the National Academy of Sciences USA 84 50825086

Inoue S, Orimo A, Hosoi T, Matsuse T, Hashimoto M, Yamada R, Ouchi Y, Orimo H and Muramatsu M (1993) Expression of follistatin, an activinbinding protein, in vascular smooth muscle cells and arteriosclerotic lesions Arteriosclerosis and Thrombosis 13 I859-1864

Kaipia A, Penttila TL, Shimasaki S, Ling N, Parvinen M and Toppari J (1992) Expression of inhibin $\beta_{A}$ and $\beta_{B}$, follistatin and activin- $A$ receptor messenger ribonucleic acids in the rat seminiferous epithelium Endocrinology 131 2703-2710

Klein R, Robertson DM, Shukovski L, Findlay JK and de Kretser DM (1991) The radioimmunoassay of FSH-suppressing protein (FSP): stimulation of bovine granulosa cell FSP secretion by FSH Endocrinology 128 1048-1056

Kogawa K, Nakamura T, Sugino K, Takio K, Titani K and Sugino H (1991a) Activin-binding protein is present in pituitary Endocrinology 128 1434-1440

Kogawa K, Ogawa K, Hayashi Y, Nakamura T, Titani K and Sugino H (1991b) Immunohistochemical localisation of follistatin in rat tissues Endocrinologia Japonica 38 383-391 
Laemmli UK (1970) Cleavage of structural proteins during assembly of the head of the bacteriophage $T_{4}$ Nature 227 680-685

Lin T, Harrington Calkins J, Morris PL, Vale W and Bardin CW (1989) Regulation of Leydig cell function in primary culture by inhibin and activin Endocrinology 125 2134-2140

Loveland KL, Hedger MP, Risbridger GP, Herszfeld D and de Kretser DM (1993) Identification of receptor tyrosine kinases in the rat testis Molecular Reproduction and Development 36 440-447

Mather JP, Attie KA, Woodruff TK, Rice GC and Phillips DM (1990) Activin stimulates spermatogonial proliferation in germ-Sertoli cell cocultures from immature rat testis Endocrinology 127 3206-3214

Mather JP, Roberts PE and Krummen LA (1993) Follistatin modulates activin activity in a cell and tissue specific manner Endocrinology 132 2732-2734

Mathews LS (1994) Activin receptors and cellular signalling by the receptor serine kinase family Endocrine Reviews 15 310-325

Meinhardt A, Seitz J, McFarlane JR and de Kretser DM (1996) Activin A maintains the differentiated state of meiotic germ cell mitochondria in vitro. Proceedings of the 10th International Congress of Endocrinology San Francisco, USA, June 1996 Vol. Il p. 824. Endocrine Society Press, Bethesda, MD

Michel U, Albiston A and Findlay JK (1990) Rat follistatin: gonadal and extragonadal expression and evidence for alternative splicing Biochemical and Biophysical Research Communications 173 401-407

Michel U, Esselmann J and Nieschlag E (1993) Expression of follistatin messenger ribonucleic acid in Sertoli cell-enriched cultures: regulation by epidermal growth factor and protein kinase $\mathrm{C}$-dependent pathway but not by follicle-stimulating hormone and protein kinase A-dependent pathway Acta Endocrinologica 129 529-531

Michel U, Schneider O, Kirchhof C, Meisel S, Smirnov A, Wiltfang J and Reickmann P (1996) Production of follistatin in porcine endothelial cells: differential regulation by bacterial compounds and the synthetic glucocorticoid RU 28362 Endocrinology 137 4925-4934

Nakamura T, Takio K, Eto Y, Shibai H, Titani K and Sugino H (1990) Activinbinding protein from rat ovary is follistatin Science 247 836-838

Nakamura T, Sugino K, Titani K and Sugino H (1991) Follistatin, an activin binding protein, associates with heparan sulfate chains of proteoglycans on follicular granulosa cells Journal of Biological Chemistry $266 \quad 19432-19437$
Nakamura T, Hashimoto O, Shoji H, Sugino K and Sugino H (1996) The role of follistatin in activin signal transduction Proceedings of Serono Symposium on Inhibin, Activin and Follistatin - Recent advances and Future View', Tokushima Japan Abstract L27. Serone Symposia, SA

Phillips DJ, Hedger MP, McFarlane JR, Klein R, Clarke IJ, Tilbrook AJ, Nash AD and de Kretser DM (1996) Follistatin concentrations in male sheep increase following sham castration/castration or injection of interleukin-1 $\beta$ Journal of Endocrinology 151 119-124

Robertson DM, Klein R, de Vos FL, McLachlan RI, Wettenhall REH, Hearn MTW, Burger HG and de Kretser DM (1987) The isolation of polypeptides with FSH suppressing activity from bovine follicular fluid which are structurally different to inhibin Biochemical and Biophysical Research Communications 149 744-749

Sambrook J, Fritsch EF and Maniatis T (1989) Gel electrophoresis of DNA. In Molecular Cloning: A Laboratory Manual (2nd Edn) Eds N Ford, C Nolan and M Ferguson. Cold Spring Harbor Laboratory Press, NY

Schneyer Al, Rzucildo DA, Sluss PM and Crowley WF, Jr (1994) Characterization of unique binding kinetics of follistatin and activin or inhibin in serum Endocrinology 135 667-674

Shimasaki S, Kaga M, Esch F, Mercado M, Cooksey K, Koba A and Ling N (1988) Porcine follistatin gene structure supports two forms of mature follistatin produced by alternative splicing Biochemical and Biophysical Research Communications 152 717-723

Shimasaki S, Koga M, Buscaglia ML, Simmons DM, Bicsak TA and Ling N (1989) Follistatin gene expression in the ovary and extragonadal tissues Molecular Endocrinology 3 651-659

Sugino K, Kurosawa N, Nakamura T, Takio K, Shimasaki S, Ling N, Titani K and Sugino H (1993) Molecular heterogeneity of follistatin, an activin-binding protein Journal of Biological Chemistry 26815 579-15 587

Ueno N, Ling N, Ying S, Esch F, Shimasaki S and Guillemin R (1987) Isolation and partial characterisation of follistatin: a single chain Mr 35,000 monomeric protein that inhibits the release of follicle stimulating hormone Proceedings of the National Academy of Sciences USA $848282-8286$

Wray W, Boulikas T, Wray VP and Hancock R (1981) Silver staining of proteins in polyacrylamide gels Analytical Biochemistry 118 197-203 